\title{
Remote sensing of glacier change in West Greenland: accounting for the occurrence of surge-type glaciers
}

\author{
Michele CITTERIO, ${ }^{1}$ Frank PAUL, ${ }^{2}$ Andreas P. AHLSTRØM, ${ }^{1}$ Hans F. JEPSEN, ${ }^{1}$ \\ Anker WEIDICK ${ }^{1}$ \\ ${ }^{1}$ Geological Survey of Denmark and Greenland, Øster Voldgade 10, DK-1350 Copenhagen, Denmark \\ E-mail: mcit@geus.dk \\ ${ }^{2}$ Department of Geography, University of Zürich-Irchel, Winterthurerstrasse 190, CH-8057 Zürich, Switzerland
}

\begin{abstract}
Automated glacier mapping from thresholded band ratios of multispectral satellite data is a well-established technique to update glacier inventories over large and remote regions. The local glaciers and ice caps on Greenland are of particular interest for such efforts, as they have been only partly mapped, mainly during the 1940s-60s, and their potential contribution to global sea-level rise could be large. Here we use three Landsat ETM+ scenes from 2001 covering Disko Island (Qeqertarsuaq) and the Nuussuaq and Svartenhuk peninsulas, West Greenland, to map the glacier extent in 2001 of 1172 entities. We also manually digitize Little Ice Age (LIA) extents from clearly visible trimlines for a subsample of $\mathbf{5 0 0}$ entities. In this region with numerous surge-type glaciers, the related area-change calculation is challenging and we consider different samples with and without known surging glaciers. For the three regions the mean area changes are $-28 \%,-20 \%$ and $-23 \%$, respectively, when known surge-type glaciers are excluded. The glaciers on smaller islands and peninsulas closer to the margin of the ice sheet show a lower mean area change of $-15 \%$. Moreover, lower $(-16 \%)$ and upper $(-21 \%)$ bounds are calculated for the overall area changes in the entire region between the LIA and 2001 using different upscaling assumptions. Cumulative length changes since the LIA are found to be slightly lower for surge-type glaciers.
\end{abstract}

\section{INTRODUCTION}

Glaciers and ice caps are recognized as the main contributors to sea-level rise for the past and current centuries (Meier and others, 2007), and the Arctic is expected to undergo a particularly marked warming in the coming decades (e.g. ACIA, 2004; Solomon and others, 2007). Mapping of the current extent of ice masses outside the Greenland ice sheet (termed local glaciers in the following) is therefore needed to establish a benchmark against which to quantify past and future changes. According to the 'Glacier inventory and atlas of West Greenland' (Weidick and others, 1992), 5300 local glaciers exist between the coastline and the western margin of the ice sheet up to $71^{\circ} \mathrm{N}$. They cover nearly all types from the primary classification of inventory data (PSFG, 1977): ice caps with and without outlet glaciers, valley and mountain glaciers as well as cirques and glacierets. Moreover, several surging glaciers are known to exist on Disko Island (Qeqertarsuaq) and the Nuussuaq peninsula (Yde and Knudsen, 2007). The first aim of this work is therefore to map glacier extents and assess area changes of local glaciers in this specific region in West Greenland. The previous inventory provides both detailed inventory data (including topographic attributes) and a comprehensive overview of the region through maps of glacier outlines and codes; however, it was compiled from aerial photography mainly acquired between the 1940s and 1960s, and it is now appropriate to repeat it.

Because glacier inventories necessarily refer to a given point in time (or period), they must be used with caution as a reference for change assessment in regions where surge-type glaciers occur, as their specific behaviour can impact on the results of overall glacier area or length change calculations.
The Disko-Nuussuaq surge cluster (Yde and Knudsen, 2007) and surrounding regions thus offer an interesting target for glacier mapping and change assessment. Hence, a further aim of this study is to assess the impact of known surge-type glaciers on the change assessment, and to investigate to what extent surge-type glaciers can be identified based on their area or length changes compared to an earlier point in time. This last result could also potentially help in identifying surge-type glaciers in other arctic regions. The maximum glacier extent from the Little Ice Age (LIA) is highly visible in multispectral (optical) satellite imagery in this Arctic region, as trimlines and vegetation-free glacier forefields clearly stand out (Csatho and others, 2005; Paul and Kääb, 2005; Wolken, 2006). According to Dowdeswell (1995), the LIA maximum might have occurred around the 1920s in this region, while Yde and Knudsen (2007) point to the end of the 19th century. It should be noted that rock glaciers are particularly abundant in the study region (Humlum, 1988) and pose an additional challenge in delineating the LIA glacier extent for several glaciers. In the Disko-Nuussuaq region it is also possible that a few apparent LIA trimlines actually originated from surges, which introduces additional uncertainty into the timing of the calculated changes.

Paul and others (2002) showed that automated mapping of glacier outlines from optical satellite imagery over large regions is feasible with a reasonable effort, and that their method is robust against common problems encountered in high-relief mountain terrain, such as shadow areas (see also Paul and Kääb, 2005). The same method is applied here to map the local glaciers and create vector outlines in a digital format for 2001 from Landsat Enhanced Thematic Mapper Plus (ETM+) data. These outlines will finally also contribute to the database of the Global Land Ice Measurements from 
Space (GLIMS) initiative, which aims to compile a digitally available and freely accessible database of glacier outlines around the world (Raup and others, 2007). The outlines for local glaciers on Greenland are still missing in the GLIMS database, although several studies related to global sea-level rise calculations indicated an urgent need for them (e.g. Raper and Braithwaite, 2006; Meier and others, 2007).

The study area is particularly suited to this type of investigation for a number of reasons: (1) easily recognizable trimlines and moraines from the LIA allow change assessment from remote-sensing datasets; (2) overall changes in a region with many surging glaciers have not been investigated thus far; (3) a number of potential surgetype glaciers have been identified in a previous study and could be used here to investigate differences in behaviour; (4) the area is only partly included in the former glacier inventory; (5) compilation of the part already included took place between the 1940s and 1960s and should thus be repeated; (6) the region is not yet covered by the GLIMS database; (7) cloud-free and already orthorectified Landsat ETM+ data from the end of the ablation period with little remaining seasonal snow are available; (8) a digital elevation model (DEM) is also available for the region south of $71^{\circ} \mathrm{N}$ for the calculation of topographic glacier parameters and drainage divides.

In order to deal quantitatively with uncertainties in assessing overall area changes for the entire region from a reduced sample of reliably delineated LIA outlines, we calculated lower and upper bounds of the overall changes. For the lower bound it is assumed that all glaciers without a mapped LIA extent did not change at all, while for the upper bound the observed changes per size class are applied to all glaciers. In both cases, the changes are calculated from two samples, one including and one excluding all known surging glaciers.

\section{Study site and datasets}

The investigated region stretches from Disko Island to the Nuussuaq and Svartenhuk peninsulas $\left(\sim 69-72^{\circ} \mathrm{N}, 51-\right.$ $\left.55^{\circ} \mathrm{E}\right)$, encompassing most of the glacierized regions between the Baffin Bay eastern coastline and the western margin of the ice sheet (Fig. 1). Three consecutive and already orthorectified Landsat ETM+ scenes were downloaded for free from the Global Land Cover Facility (GLCF) server. All Landsat ETM+ scenes (path 13, rows 9-11) were acquired on 4 August 2001 under excellent conditions (i.e. cloud-free and mostly no seasonal snow outside glaciers). For the southern part of the test region (south of $71^{\circ} \mathrm{N}$ ), a DEM with $50 \mathrm{~m}$ cell spacing was created from $100 \mathrm{~m}$ contour lines and additional vector data. DEM data were thus not available for the northern scene (path 13, row 11) and the upper third of the middle scene (path 13, row 10). In these regions, drainage divides were assigned by visual interpretation of illumination differences, and detailed inventory data were not generated. For the region south of $71^{\circ} \mathrm{N}$, we could also use a vector dataset with outlines of all contiguous ice masses, created from topographic maps acquired by aerial photography in 1984. Unfortunately, the dataset with the World Glacier Inventory coordinates (Weidick and others, 1992) lacks the resolution needed to assign the former inventory code directly. We therefore moved the former code manually to the position of the respective glacier. Yde and Knudsen's (in press) comprehensive list of surge-type glaciers covering Disko Island was used to assign an additional identifier in the attribute table of the respective glacier entities both on the 2001 and LIA extent. This attribute was directly transferred to the 2001 and LIA entities by the glacier identification codes from Weidick and others (1992) as used by Yde and Knudsen (in press). LIA entities flagged as surge-type which later split into independent smaller glaciers are identified by a separate code.

\section{METHODS \\ DEM generation}

A DEM with $50 \mathrm{~m}$ grid spacing was derived from the contour lines and the additional vector datasets using the TOPOGRID interpolation (Hutchinson, 1989) implemented in the Arclnfo Geographic Information System (GIS) software package. Although these maps are based on aerial photogrammetric surveys from 1984, they were used together with the glacier outlines from 2001. Given the likely reduced accuracy over glacierized surfaces, the 16 year gap between the DEM and the 2001 glacier outlines was neglected. The DEM is mainly used to derive a flow direction grid (i.e. the aspect of downhill flow in eight cardinal directions) which helped in digitizing drainage divides for a clearer separation of glaciers in the accumulation area. In Figure 2a an example is given showing both the digitized ice divides based on illumination differences and those from the flow direction grid. In a few cases, the area change due to a wrongly positioned drainage divide could be much larger than the real area changes (Paul and Andreassen, 2009). The DEM is further used to calculate the area-elevation distribution (hypsometry) in 100 m elevation bands, and to obtain topographic glacier parameters (e.g. minimum, mean and maximum elevation, mean slope and aspect) for each selected entity.

\section{Glacier outlines from ETM+}

Glacier outlines were obtained from the three Landsat ETM+ scenes by automated techniques using a thresholded band ratio as proposed by Paul and others (2002). This method exploits the strong contrast between the high reflectance of ice and snow in the visible and near-infrared (VNIR) part of the spectrum (e.g. with Landsat ETM+ band 3, 630-690 nm) and the low reflectance in the shortwave infrared (SWIR) where band $5(1550-1750 \mathrm{~nm})$ is located. In detail, the work flow for classifying the nearest-neighbour resampled multispectral images from GLCF includes (see Fig. 3):

application of a median filter $(3 \times 3$ kernel $)$ to band 5 for noise reduction,

dividing the (filtered) digital numbers (DN) of band 3 by band 5,

setting an empirical threshold to obtain raw glacierized areas, and

applying a median filter to reject artefacts due to noise (small snowpatches or shadow regions) in the input rasters.

The threshold for the ratio image is selected in the most sensitive region (shadow), with the aim of a minimal workload for post-processing (i.e. required manual editing). After raster-vector conversion, manual editing is applied to exclude lakes and add debris-covered ice. Basin boundaries (drainage divides) are digitized in a separate layer to split 


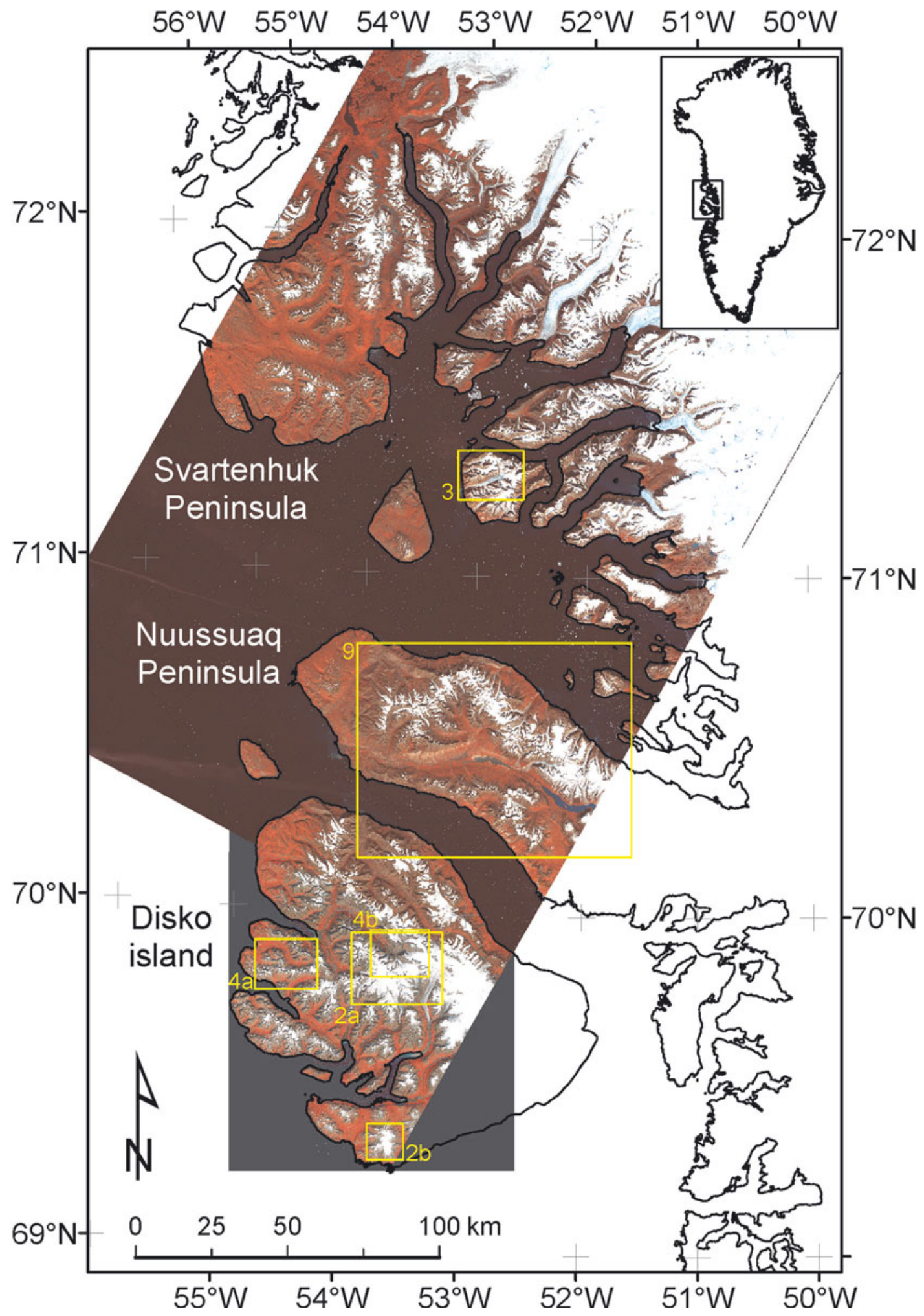

Fig. 1. Overview showing the location of Disko Island and the Nuussuaq and Svartenhuk peninsulas, West Greenland, based on the three Landsat ETM+ scenes from 8 August 2001 used in this study. Inset is the location of the study site within Greenland. Yellow boxes denote the location of further figures.

contiguous ice masses into individual glaciers and to exclude snowfields. In Figure $2 \mathrm{~b}$ a small ice cap with outlet glaciers on southern Disko Island is shown, illustrating challenging snow conditions and the digitized separation from the snowfields. Several glaciers have been excluded in the southern part of the scene (path 13, row 11) from the originally mapped sample due to similar adverse snow conditions.

\section{LIA trimlines}

Finally, the LIA extent was interpreted and digitized at glaciers where this could be done with reasonable confidence using easily recognizable trimlines and moraines as an indicator (e.g. Paul and Kääb, 2005; Wolken, 2006). It is possible that a few of the mapped LIA extents are in fact connected to recent surges. Since the level of detail required for proper recognition of typical surge-related landforms is 

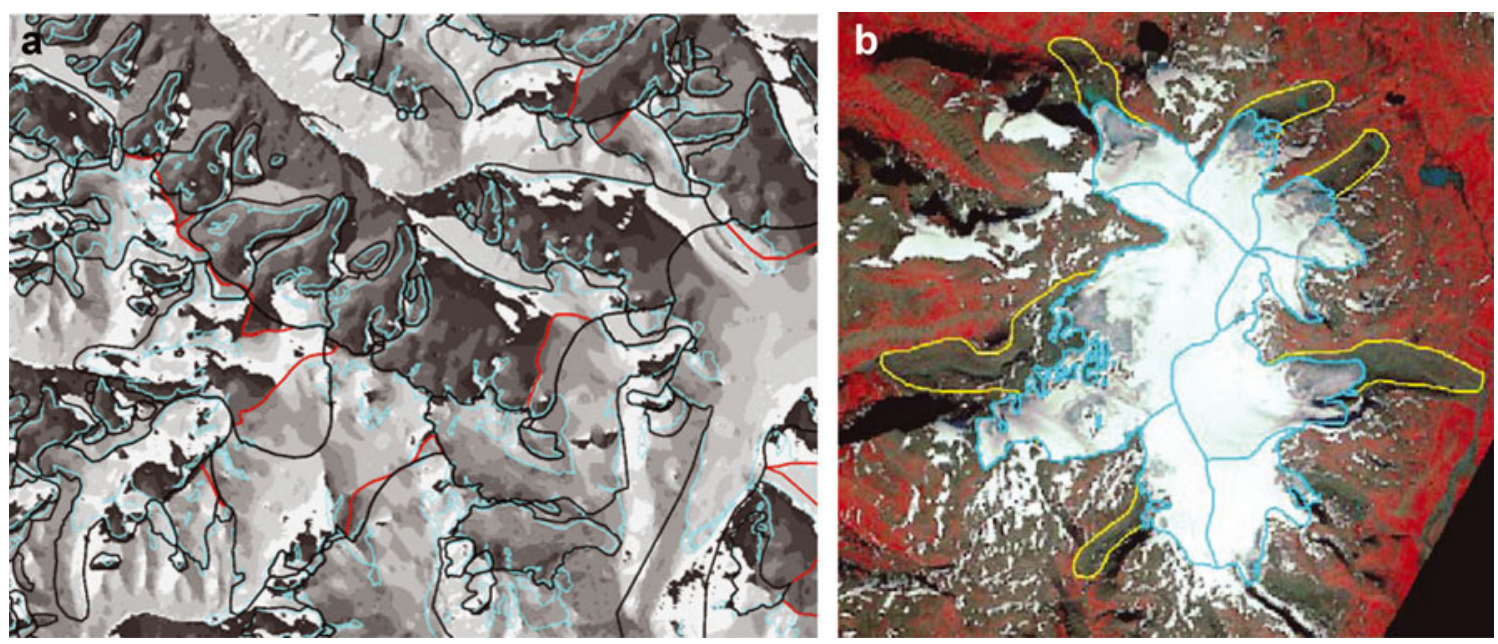

Fig. 2. Two examples of challenging targets for delineating glacier boundaries (see Fig. 1 for location): (a) digitized ice divides based on illumination differences (black), and those derived from the flow direction grid (red), which is shown in greyscale in the background; (b) splitting contiguous ice masses and excluding snowfields at a small ice cap in southern Disko Island. Yellow lines mark the interpreted maximum LIA extent, blue lines the extent in 2001.

in general not present in the ETM+ data, the list of surge-type glaciers from Yde and Knudsen (in press) was used. Due to the abundant rock glaciers, a few glacier forefields were disregarded as an indicator of LIA extent. While illumination normally allows (active) rock glaciers (with a steep front and convex curvature) to be distinguished from vegetation-free land in the forefield (no steep front and with a concave curvature), for some forefields this was unclear and LIA extents were not mapped (Fig. 4a). Glacier outlines for the LIA and for 2001 are given an individual ID number to facilitate the computation of area changes on each glacier as well as the entire LIA entity. Since their LIA maximum extent, several larger glaciers have split into two or more individual glaciers. This implies that aggregate area changes are calculated for the glacier units belonging to the former compound glacier.

\section{Length changes}

Length changes are difficult to define in the case of glaciers that split. In this study, two approaches have been used to assign glacier length and calculate the related changes. In the case of tributaries that might not have made a large contribution to the major flow, the former glacier end was assigned at the point where the tributary joins the major flowline of the system (Fig. 4b). In the case of a similar contribution by tributaries, flowlines were digitized down to the LIA terminus for all these tributaries individually. Hence, in these cases the derived length changes are subject to some uncertainty, meaning that for small tributaries parallel flow is effectively neglected and the digitized LIA lengths could be too short, and the converse.

\section{Area changes}

A direct comparison of area changes with the former glacier inventory data (Weidick and others, 1992) has not been performed, as the data in that list were compiled over too long a time span (between the 1940s and the 1960s) and the formerly used drainage divides are not digitally available. Compared with the digitally available vector outlines from 1984 (south of $71^{\circ} \mathrm{N}$ ), only small changes (retreat) took place until 2001 for nearly all glaciers. On the other hand, a few glaciers, especially on Disko Island, had (partly massive) surges in between (Yde and Knudsen, 2005), with area gains that exceeded the small overall area loss of the entire region in that period. In consequence, glacier changes from the LIA to 1984 and from 1984 to 2001 were only computed as an aggregate figure for the Nuussuaq peninsula.

A grid with a $10 \mathrm{~km} \times 10 \mathrm{~km}$ cell size of the spatially averaged per cent area change over a $50 \mathrm{~km} \times 50 \mathrm{~km}$ neighbourhood has been produced to observe the regional distribution of glacier change (Fig. 5) and as an aid to detect regions displaying very different behaviour from their neighbours. This assisted in pinpointing operator errors, but could also detect the occurrence of a surge or the existence of a debris-covered glacier experiencing a reduced change. It is important, however, to consider that significant variability of glacier area and length changes is common even for glaciers very close to each other, depending on their respective size, hypsometry and aspect.

The glacier change assessment was carried out for two subsets of glaciers for which LIA extents could be determined reliably, one including and one excluding the surging glaciers. To obtain the changes for the entire sample, we applied two assumptions revealing lower and upper bounds for the changes. The first assumption is that all glaciers where the LIA extent could not be mapped (for whatever reason) have not changed in size since the LIA. The second assumption is that all glaciers behaved like those where LIA extents could be mapped. For the latter we used size-class specific changes to upscale to the entire dataset (see Paul and others, 2004).

\section{RESULTS}

A total of 1172 glaciers were mapped, covering $3832 \mathrm{~km}^{2}$ in 2001. In this sample, $72 \%$ of glaciers are smaller than $5 \mathrm{~km}^{2}$ and cover $23 \%$ of the area (Fig. 6), whereas glaciers larger than $50 \mathrm{~km}^{2}$ account for $8 \%$ of the total number and $47 \%$ of the total area. This strong bias toward a large number of smaller glaciers, and a few larger glaciers covering most of the glacierized surface, is typical for many glacierized regions. A similar bias in the area and number distribution is also found for the 500 glaciers whose LIA outlines could be delineated and area changes calculated (Table 1). The total 

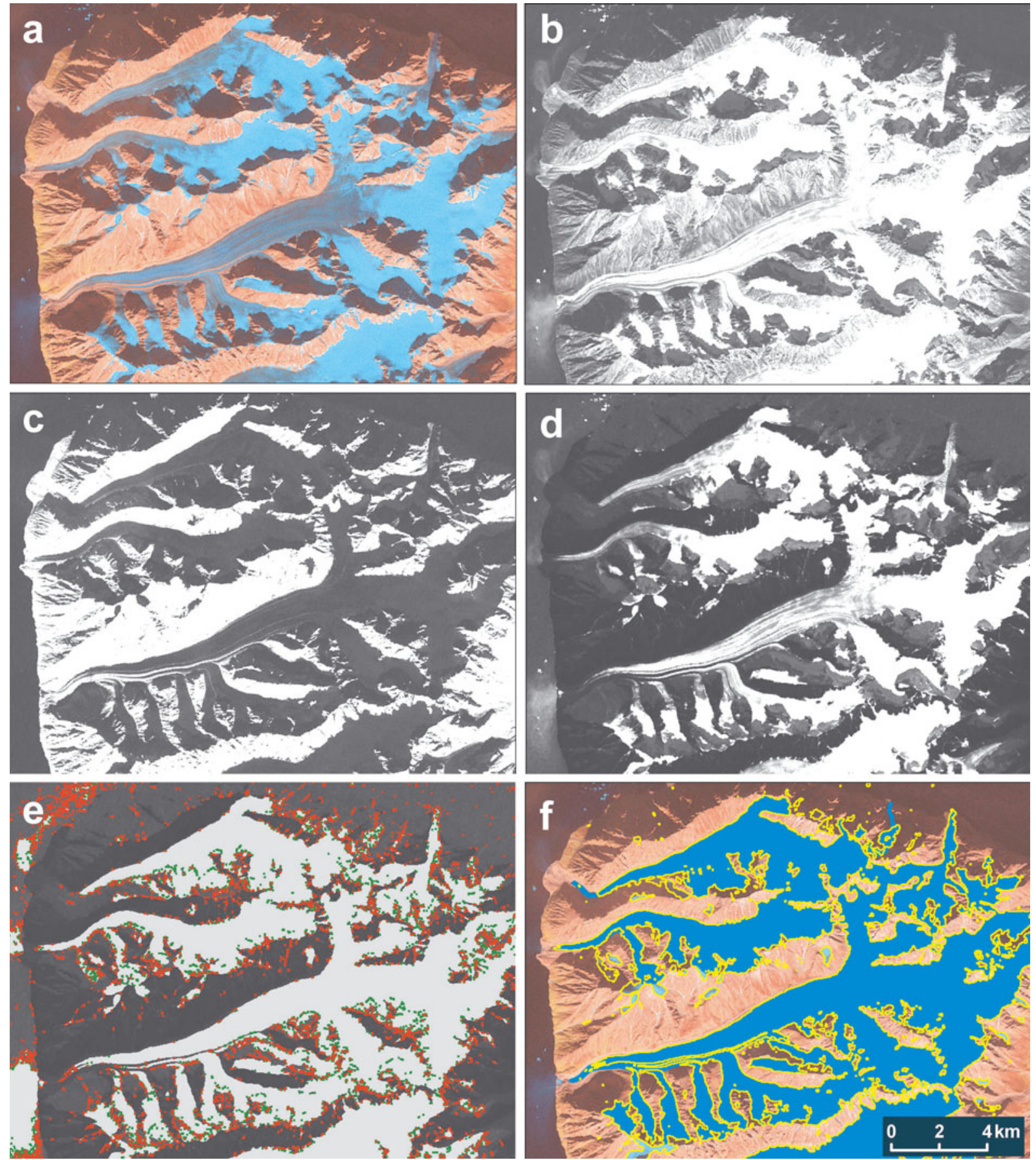

Fig. 3. Overview of the steps involved in the band ratio method (see Fig. 1 for location): (a) test region for Upernivik Island to the north of Nuussuaq peninsula using a false-colour composite with ETM+ bands 5, 4 and 3 as red, green and blue, respectively; (b) the region as seen with ETM+ band 3; (c) as (b) but with band 5; (d) the resulting band 3/5 ratio image; (e) resulting glacier map (grey) using a threshold of 2 (red pixels were deleted by the majority filter, blue pixels added); and ( $f$ ) glacier outlines after raster-vector conversion (yellow) and manually corrected regions (blue).

area covered in 2001 and at the LIA maximum by glaciers belonging to seven different size classes decreased from $3726 \mathrm{~km}^{2}$ to $2990 \mathrm{~km}^{2}$, an area loss of $736 \mathrm{~km}^{2}$ or $19.8 \%$ (Fig. 6b). The total number of individual glaciers mapped in 2001 is higher by 160 units than at the end of the LIA (Fig. 6a) due to the widespread split of the LIA glaciers (see Fig. 4a). Glaciers smaller than $0.5-1 \mathrm{~km}^{2}$ underwent the greatest shrinkage relative to initial size, with an average loss of about $40 \%$ of their area (Table 1). On Disko Island, where most known surge-type glaciers are located, this change vs size pattern is essentially the same whether only the normal glaciers or both normal and surge-type glaciers (Fig. 7) are considered. The effect of excluding known surge-type glaciers reduces the mean area loss by nearly $5 \%$ on Disko Island but less than $1 \%$ overall for the entire region.

A scatter plot depicting relative area changes vs glacier area for individual glaciers is shown in Figure 8. In contrast to findings from other regions (e.g. Paul and others, 2004; Paul and Kääb, 2005), the scatter of values is already comparably high for large glaciers $\left(>20 \mathrm{~km}^{2}\right)$. However, as in several other regions, a certain dependence of the relative change on initial size is observed when aggregated over 

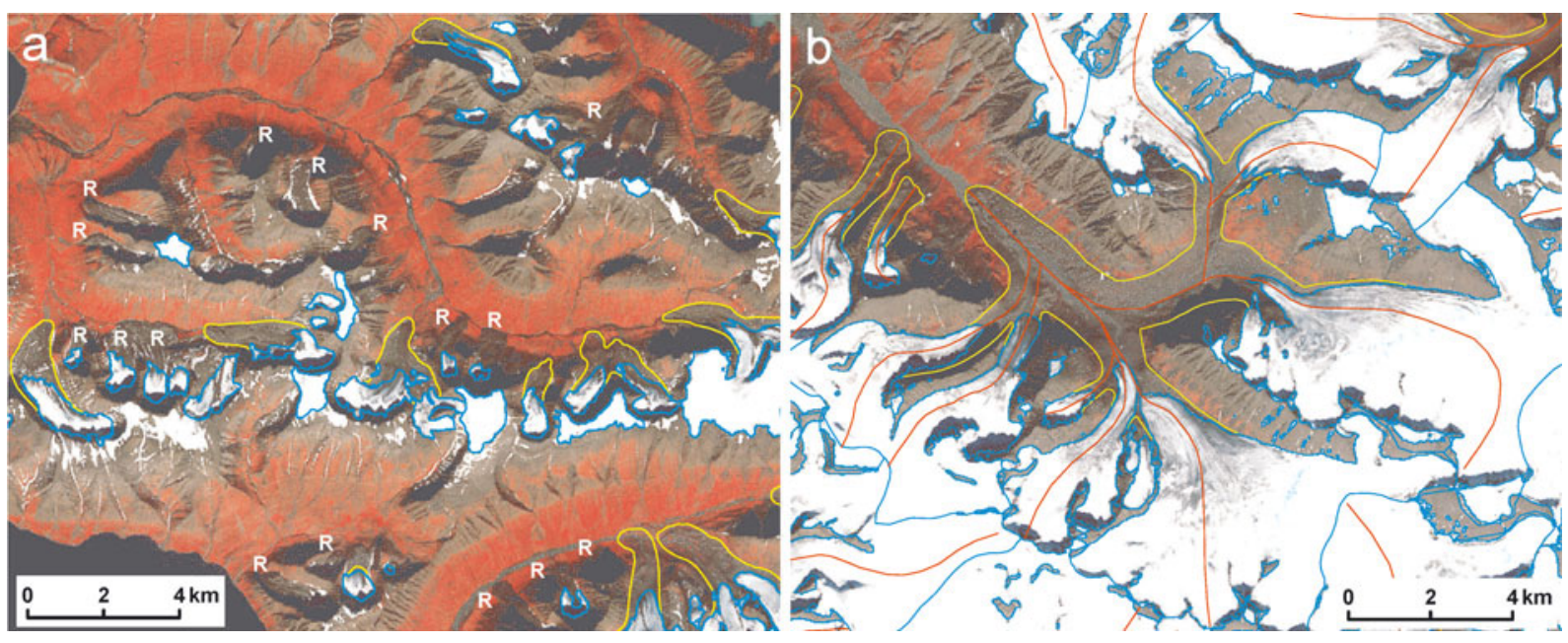

Fig. 4. (a) Abundant rock glaciers (R) are visible in this region of Disko Island, which hinders the identification and mapping of the LIA extents (yellow) of several glaciers (light blue outlines); (b) example of central flowlines (red) as mapped for a formerly compound-basin valley glacier (yellow) on Disko Island (see Fig. 1), which split into several entities (light blue) before 2001. In this case, the flowlines of all tributaries are only digitized to the confluence point with the main glacier (which is of surge type).

distinct size classes. The scatter plot of Figure 8 displays the three main regions by means of different symbols based on the three Landsat scenes. The change pattern is similar for all three regions.

On the Svartenhuk peninsula, excluding other minor peninsulas and islands in the northern part of the investigated area, the total glacierized area was $629 \mathrm{~km}^{2}$ in 2001 . Excluding those glaciers without a LIA extent, we found a $-23.0 \%$ change in glacierized area, from $769 \mathrm{~km}^{2}$ to $592 \mathrm{~km}^{2}$, from the LIA to 2001. Similarly, aggregate total glacierized area on the Nuussuaq peninsula in 2001 was $804 \mathrm{~km}^{2}$. In the same area we outlined the LIA extent of 110 glaciers (Fig. 9), which shrank from their maximum extent of $917 \mathrm{~km}^{2}$ at the LIA to $736 \mathrm{~km}^{2}$ in $2001(-19.7 \%)$. The mapped glacierized area on Disko Island was $1175 \mathrm{~km}^{2}$ in 2001; when only considering glaciers with mapped LIA extents and further excluding known surge-type glaciers, the area reduction corresponds to $-27.6 \%$ (from $345 \mathrm{~km}^{2}$ to $250 \mathrm{~km}^{2}$ ). When surge-type glaciers are included, the overall loss is somewhat smaller $(-23.1 \%)$, corresponding to a
LIA-2001 shrinkage from 953 to $733 \mathrm{~km}^{2}$. Regional glacier change data are summarized in Table 2.

The values for the area changes in the entire region as measured for the glaciers with both 2001 and LIA extent and as derived from the zero-change and upscaling assumptions are also listed in Table 2. Assuming that all glaciers for which the LIA extent has not been mapped have not changed at all, we obtain a lower bound of the change for the entire region that is certainly too small. On the other hand, the value derived from upscaling with the measured changes results in an upper bound of the area change. The range thus quantifies and constrains the uncertainty in the change assessment. For the entire study region, the overall relative glacierized area change can thus be estimated at about $-20 \%$, constrained within the lower $-16 \%$ bound and the upper $-21 \%$ bound.

Two methods have been used to locate potentially anomalous glaciers. One is based on comparing the change value for any single glacier against the raster grid of LIA-2001 averaged percentage area change (Fig. 5). This conveniently

Table 1. Glacier number and area change vs size class from the LIA to 2001. Values are given both for the entire sample and for the subsample of glaciers with LIA information. Estimated values of LIA glacierized area are also provided from upscaling based on size-class specific changes observed for the subset of glaciers with LIA information

\begin{tabular}{|c|c|c|c|c|c|c|c|}
\hline \multirow[t]{2}{*}{ Size class } & \multicolumn{2}{|c|}{ Number of glaciers in 2001} & \multicolumn{2}{|c|}{ Glacierized area in 2001} & \multirow{3}{*}{$\begin{array}{l}\text { Glacierized area, LIA } \\
\text { Subsample } \\
\text { with LIA data } \\
\mathrm{km}^{2}\end{array}$} & \multirow{3}{*}{$\begin{array}{l}\text { LIA-2001 area change } \\
\text { Subsample } \\
\text { with LIA data } \\
\mathrm{km}^{2}\end{array}$} & \multirow{3}{*}{$\begin{array}{c}\text { Glacierized area, LIA } \\
\text { Upscaled }\end{array}$} \\
\hline & Entire sample & $\begin{array}{c}\text { Subsample } \\
\text { with LIA data }\end{array}$ & Entire sample & $\begin{array}{c}\text { Subsample } \\
\text { with LIA data }\end{array}$ & & & \\
\hline $\mathrm{km}^{2}$ & & & $\mathrm{~km}^{2}$ & $\mathrm{~km}^{2}$ & & & \\
\hline$<0.5$ & 269 & 14 & 69 & 3 & 5 & $-2(-40.4 \%)$ & 116 \\
\hline $1-5$ & 401 & 286 & 713 & 456 & 652 & $-196(-30.1 \%)$ & 1020 \\
\hline $5-10$ & 117 & 104 & 511 & 438 & 552 & $-113(-20.5 \%)$ & 643 \\
\hline $10-20$ & 90 & 88 & 691 & 664 & 806 & $-143(-17.7 \%)$ & 840 \\
\hline $20-100$ & 111 & 106 & 1505 & 1311 & 1558 & $-248(-15.9 \%)$ & 1789 \\
\hline$>100$ & 9 & 8 & 231 & 95 & 113 & $-18(-16.0 \%)$ & 275 \\
\hline Total & 1172 & 659 & 3832 & 2990 & 3726 & $-736(-19.8 \%)$ & 4871 \\
\hline
\end{tabular}




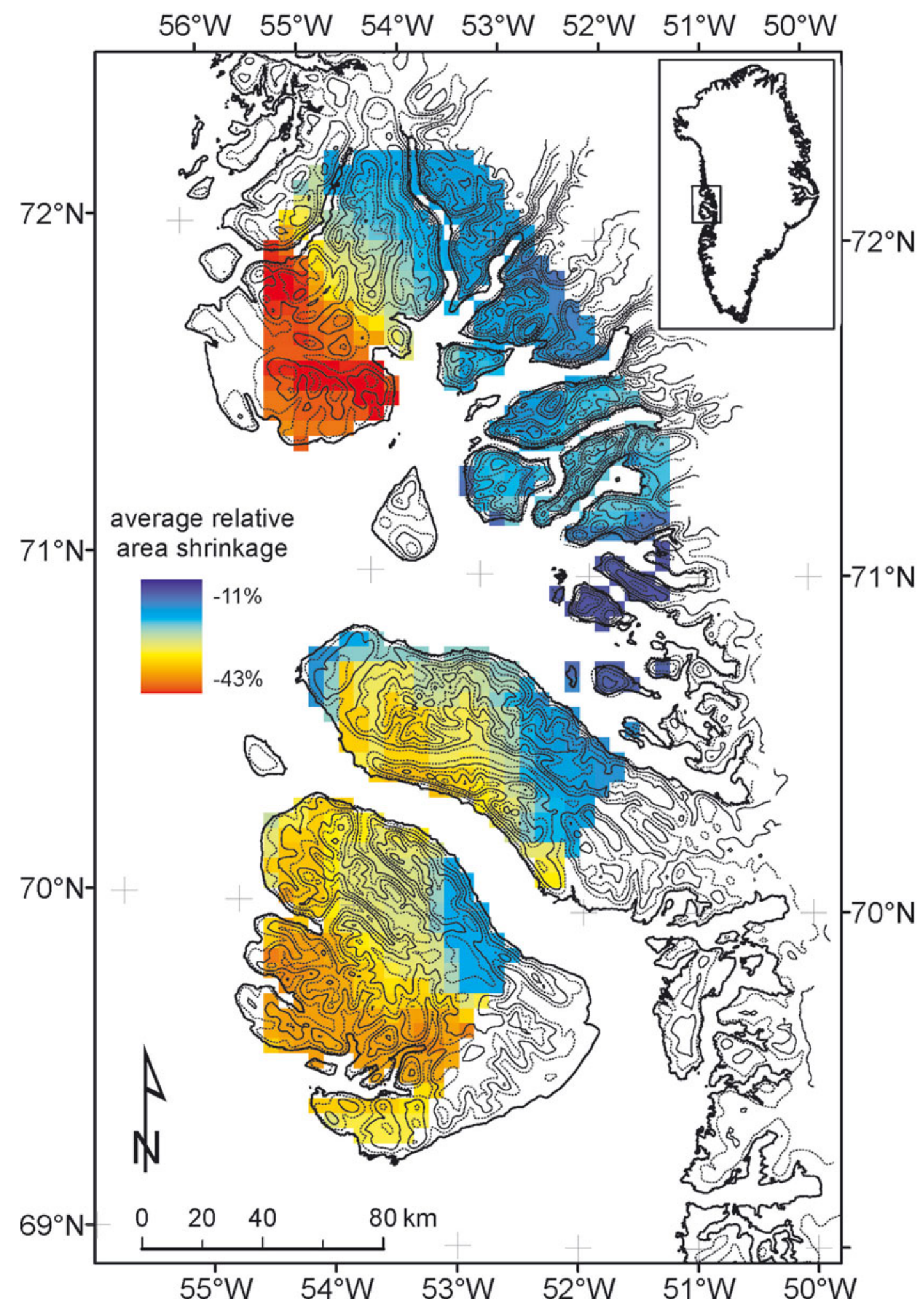

Fig. 5. Spatial variability of the LIA to 2001 relative area change over the entire region computed as $50 \mathrm{~km} \times 50 \mathrm{~km}$ average of glacier change. Yellow to red colours mark areas with larger change, blue areas smaller changes.

pinpointed any glacier behaving anomalously with respect to surrounding glaciers. Large deviations from the general pattern are often associated with surge-type glaciers and partly also with debris-covered glaciers. Yde and Knudsen's (2007, in press) list of surge-type glaciers allowed an independent control and more confident interpretation of the anomalies, but is only available for Disko Island. The second method is illustrated in the scatter plot of Figure 10, showing glacier length change vs length at the maximum LIA extent both for normal and surge-type glaciers. From this plot it is clear that long-term changes for the surging glaciers followed a trend substantially similar to that for the 'normal' glaciers. Most of them have somewhat smaller length changes than 'normal' glaciers of the same length, which could be related to their surge characteristic, though, the signal is not clear enough to derive a general rule. 



Fig. 6. (a) Comparison of glacierized area covered in every given size class, together with the relative area change, only considering glaciers for which the LIA extent is available; (b) number of glaciers in the entire sample in the LIA and 2001.

The analysis of glacier hypsometry for all distinct size classes is depicted in Figure 11. In general, the hypsometric curves of glaciers from all size classes are similar, with the $>100 \mathrm{~km}^{2}$ size classes covering comparatively more area at lower elevations. The $5-10 \mathrm{~km}^{2}$ size class is closest to the mean. Nearly $80 \%$ of the entire glacierized area in 2001 is located between 800 and $1500 \mathrm{~m}$.

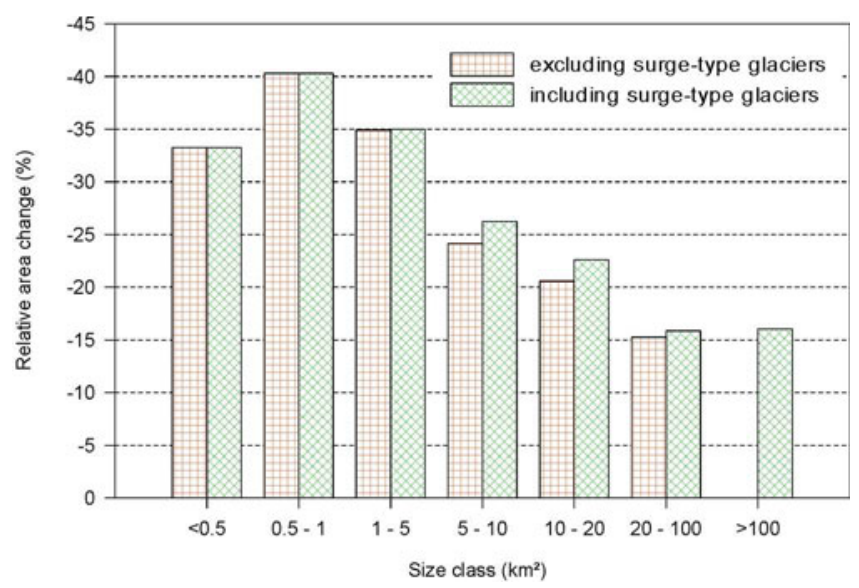

Fig. 7. Differences in relative area changes on Disko Island specific to each size class (based on LIA extents) excluding (brown) and including (green) known surge-type glaciers in the analysis.

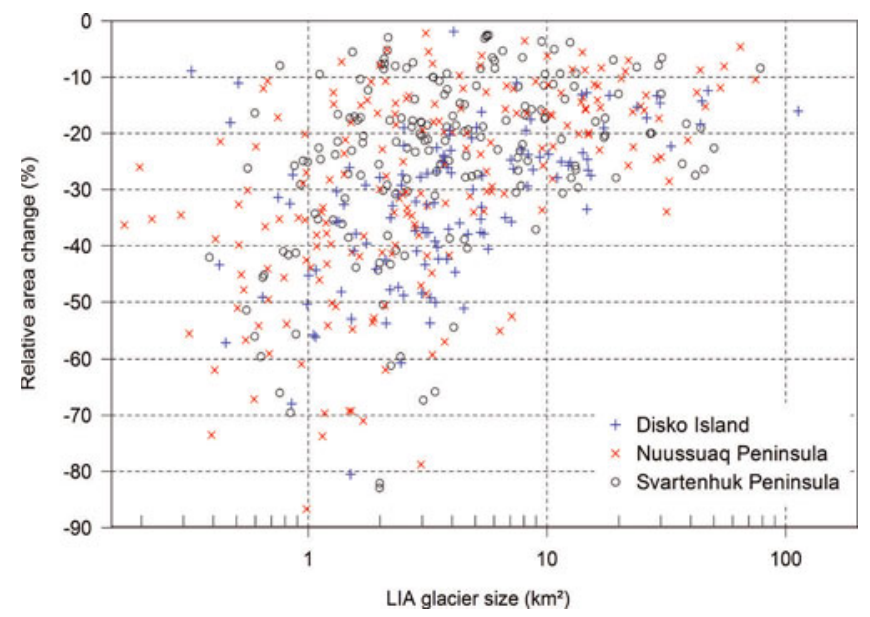

Fig. 8. Scatter plot of relative area changes vs glacier size at the LIA, grouped according to three investigated subregions.

\section{DISCUSSION}

\section{Area and length changes}

The increasing relative area loss (Figs 6 and 7) and scatter (Fig. 8) towards smaller glaciers observed for the glaciers in our study area was also been found in previous studies of different regions (e.g. Paul and others, 2004; Citterio and others, 2007; DeBeer and Sharp, 2007; Andreassen and others, 2008; Racoviteanu and others, 2008).

In our specific region, glaciers ranging in size between 0.5 and $1 \mathrm{~km}^{2}$ at their maximum LIA extent had lost $40 \%$ of their area by 2001, displaying the highest relative area reduction in the whole glacier sample. Relative area reduction consistently decreases as glaciers belonging to larger size classes are considered (Fig. 6b), with glaciers larger than $20 \mathrm{~km}^{2}$ only having lost about $16 \%$ of their maximum LIA area. The only exception to this trend is found for the smallest size class $\left(<0.5 \mathrm{~km}^{2}\right)$, which shrank slightly less than the $0.5-1 \mathrm{~km}^{2}$ class.

A peculiarity is the strong scatter in relative area change vs LIA glacier size that is already observed for the largest glaciers (Fig. 8). We interpret this as resulting both from the surge-type behaviour of many glaciers, and from the

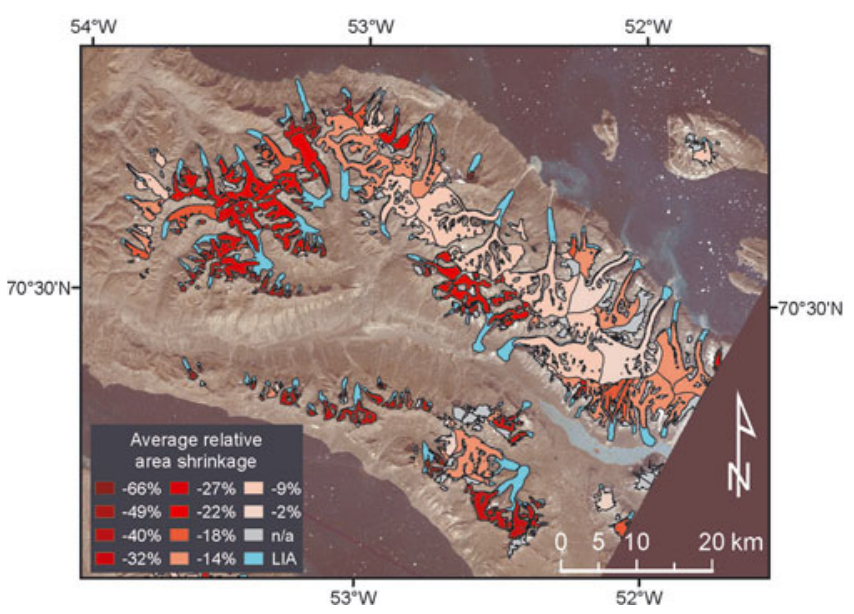

Fig. 9. Glacier area change on the Nuussuaq peninsula from the LIA to 2001 in absolute terms (light blue regions) and in relative terms (colour-coded for each glacier). 


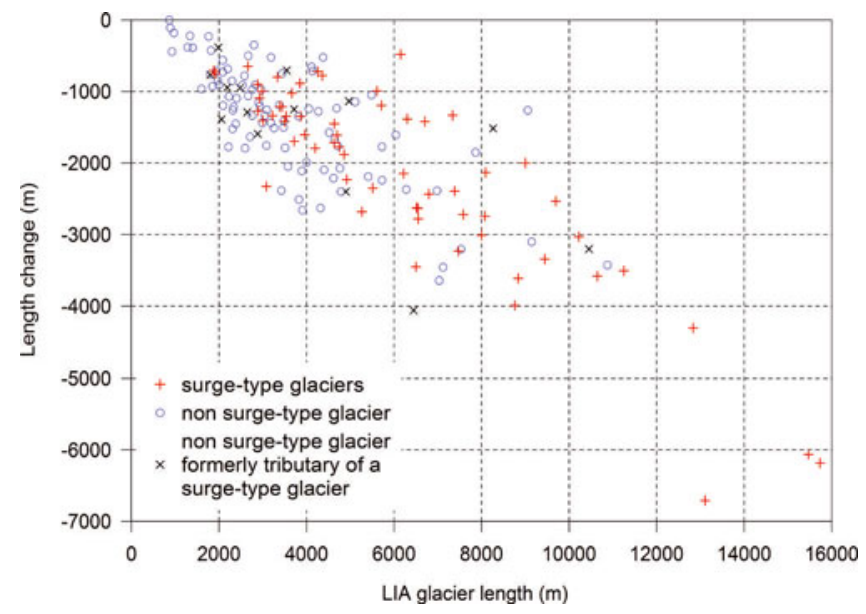

Fig. 10. Length change of surge (red crosses) vs non surge-type glaciers (blue circles) on Disko Island for which an interpreted LIA extent is available. Several 2001 glaciers not classified as surge-type by Yde and Knudsen (in press), but once tributaries of a surge-type glacier, are plotted separately (black crosses).

occurrence of very different morphologies among the largest ice masses, i.e. outlet glaciers from ice caps vs compoundbasin valley glaciers. Along with the area reduction since the LIA, glaciers from the latter type in particular split into several entities (see Fig. 4b), and the number of individual glaciers increased accordingly (Fig. 6b).

The good correlation between length changes and glacier length as seen from Figure 10 confirms that the mean length change of a larger sample of glaciers has little information when the length class distribution is not reported. Due to the surging nature of many glaciers in this region, we have not attempted to convert cumulative length change to average volume loss (e.g. Hoelzle and others, 2003; Paul and Svoboda, 2009).

\section{Surging glaciers}

The occurrence of surge-type glaciers in the region was expected to pose a challenge in determining the overall area reduction. In particular, the method of interpreting the LIA

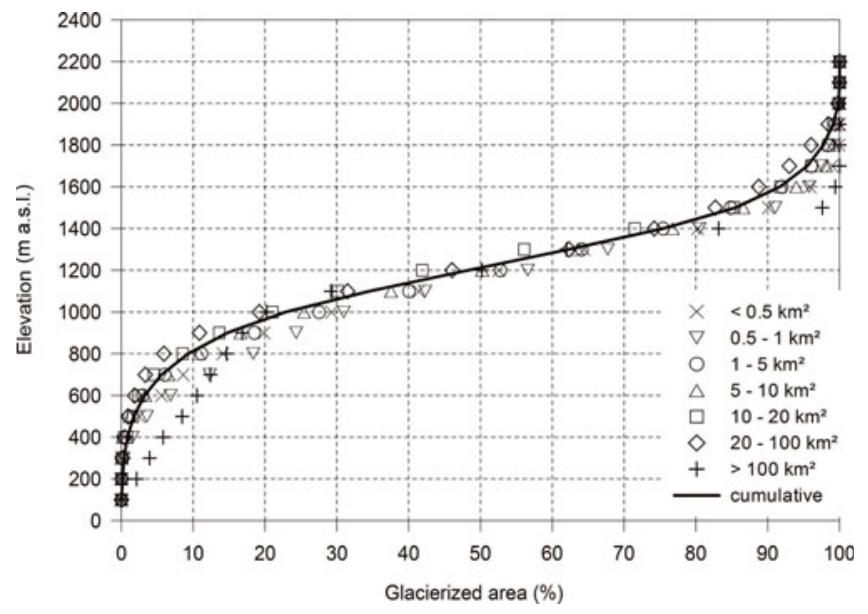

Fig. 11. Cumulative glacier hypsometry for Disko Island and the Nuussuaq peninsula. The solid black line represents all glaciers; circles represent different size classes.

outlines from Landsat ETM+ imagery might fail in the presence of surging glaciers, since the morphological evidences left by surges (e.g. trimlines) can be mistaken for LIA extents on such medium-resolution satellite datasets. This does not mean that the trimlines could not be accurately digitized, but the temporal relation remains unclear. The duration of the quiescent phase for some surge-type glaciers on Disko Island has been suggested to be $>100$ years (Yde and Knudsen, 2005). Weidick and others (1992) listed only a few Disko Island glaciers as surge-type, but a much larger number (75) were recognized in a more detailed study by Yde and Knudsen (2007). However, the decision to exclude or retain surge-type glaciers has been found to have a smaller impact on overall glacier change than the uncertainty range defined by the upper and lower bounds as calculated for the entire region. This of course may not be the case for a subregion like Disko Island with a large number of surge-type glaciers (Table 2), especially during major surge events (e.g. the recent surge of Kuannersuit Glacier on Disko Island).

Table 2. Regional overview of glacierized area change for the three main geographical subregions included in the study area (Disko Island and the Nuussuaq and Svartenhuk peninsulas) and for the other minor islands and peninsulas. The results of the change assessment are reported together with upper and lower bounds derived from different upscaling assumptions. The impact of including or excluding surgetype glaciers is only reported for Disko Island, since it is less than $1 \%$ when the entire study region is considered

Entire region

Disko Island

Incl. surge-type glaciers
Nuussuaq peninsula

\section{Svartenhuk} peninsula
Other minor islands and peninsulas
Number of glaciers in 2001

Number of glaciers with LIA data in 2001

Glacierized area in $2001\left(\mathrm{~km}^{2}\right)$

Glacierized area with LIA data in $2001\left(\mathrm{~km}^{2}\right)$

Glacierized area, LIA: digitized $\left(\mathrm{km}^{2}\right)$

Glacierized area, LIA: upscaled $\left(\mathrm{km}^{2}\right)$

Area change: lower bound (\%)

Area change: subsample with LIA data (\%)

Area change: upper bound $(\%)$

$\begin{array}{rr}1172 & 467 \\ 659 & 170 \\ 3832 & 1175 \\ 2990 & 733 \\ 3726 & 953 \\ 4871 & 1547 \\ -16.1 & -15.8 \\ -19.8 & -23.1 \\ -21.3 & -24.0\end{array}$

Excl. surge-type glaciers 


\section{Map comparison}

The total aggregated glacierized area in 1984 on the Nuussuaq peninsula from the available 1:100000 scale topographic map is $750 \mathrm{~km}^{2}$, to be compared with our Landsat-derived value of $804 \mathrm{~km}^{2}$ in 2001 (a similar comparison cannot be carried out for Disko Island because some major surge events exceed in magnitude the small overall area loss in that period). On closer examination of the 1984 and 2001 datasets, this apparent expansion is found to result from an underestimation of the glacierized area in 1984. Most discrepancies relate to debris-covered glacier ice and shadow regions which are not precisely outlined in the 1984 topographic maps. The terminus position in 2001 is clearly more advanced than in 1984 only for the two glaciers identified as 1 IB40002 and 1GH02024 in the inventory by Weidick and others (1992). Furthermore, glaciers on neighbouring Disko Island were reported as mostly stationary or in retreat, albeit at a comparatively reduced rate, between 1984 and 2005 (Yde and Knudsen, 2007). This reliability problem, together with difficulties in splitting larger 'ice' entities from the 1984 map into individual glaciers, suggests that general-purpose topographic maps are best suited for reference use as an aid during the multispectral classification, and for guidance in interpreting the landforms, but not as direct sources of glacier extents for change assessment.

\section{Spatial pattern of area change}

As to the spatial distribution of glacier change, western glaciers closer to the sea have shrunk more than glaciers further inland, with a noticeable effect of mountain ridges on the spatial distribution of glacier change (Figs 5 and 9). This effect of the comparatively high-elevation mountain ranges in the area had already been reported by Weidick and others (1992), and is reflected in a more continental climate at locations further inland. In particular, most glaciers close to the ice-sheet margin, outside Disko Island and the Nuussuaq and Svartenhuk peninsulas, show a markedly lower change. In a very few instances (e.g. on Upernivik Island), extremely low values of change may also result from large former tidewater glaciers now terminating on land but very close to the shoreline. The observed spatial distribution of glacier shrinkage is not uniform across the area. This can be seen, for example, on the Nuussuaq peninsula (Fig. 9), where the relative area-change values of the individual glaciers are colour-coded. The precipitation shadow effect on the lee side of the main mountain ridges mentioned by Weidick and others (1992) could be responsible for the different behaviour of the glaciers in the top right of the image. However, the same change pattern could also be related to the larger sizes of these glaciers, as the relative change tends to inversely correlate with glacier size (Figs 7 and 8). Taking this into account reduces the possibility of interpreting the changes in climatic terms.

\section{Accuracy}

A formal assessment of the accuracy of the mapped glacier outlines is difficult since all outlines have been visually controlled and corrected against the Landsat image. Following published work, it is assumed that the error of the derived glacier areas is in general smaller than $\pm 3 \%$ of the total area (e.g. Paul and others, 2003; Andreassen and others 2008), with an increase towards smaller glaciers (up to $10 \%$ ) and for those surrounded by seasonal snow (e.g.
Fig. 2b), where the error can exceed 20\% (Paul and Andreassen, 2009). These considerations apply immediately to the accuracy of the 'observed' change, i.e. the change value obtained on the subsample of glaciers for which not only the 2001 extent, but also the LIA extent, is available. The overall accuracy of the glacier change estimate, including uncertainties related to unclear geomorphological evidences in outlining LIA extents and the related upscaling to the entire sample, has been constrained as mentioned above by deriving upper and lower bounds for the change. In this context, it is worth summarizing how these bounds derive from two contrasting assumptions: (1) that all glaciers without a recognizable LIA trimline in the terminus forefield have remained stable (or even advanced), and (2) that the subsample of glaciers with recognizable LIA extents is representative of the whole sample. The first assumption leads to underestimation of the glacier change (it sets a lower bound), since it is clear that the LIA trimline could have been obliterated or simply made too uncertain to interpret. As to the second assumption, any stationary or advancing glacier would invalidate it, since we would not have been able to recognize and digitize any LIA outline for such a glacier, thus excluding it from the analyzed subsample and overestimating the change.

\section{CONCLUSIONS}

We have presented an analysis of glacier area changes in a region of West Greenland with numerous surging glaciers using a standard work flow of automated glacier mapping as well as trimline delineation from Landsat ETM+ data. In 2001 the glacierized area of the whole region was $3832 \mathrm{~km}^{2}$, at least $736 \mathrm{~km}^{2}(16.1 \%)$ less than at the LIA maximum. This value must be regarded as a lower bound to the loss that effectively took place, and we note that surging glaciers are also included in this sample. When surging glaciers are excluded, the overall area loss tends to be slightly higher $(<1 \%$ higher over the entire area). Overall, we estimated the relative area change for the entire study region from the LIA to 2001 to be $20 \%$, with an upper bound of $21 \%$. By calculating upper and lower bounds of the upscaled overall change, we provided a measure of the uncertainty arising from the impossibility of reliably reconstructing the LIA extent for the entire glacier sample. The criteria used in forming the glacier sample to be analyzed from the output of the multispectral processing must be carefully considered. While dependence of the relative area change on glacier size (for specific size classes) is similar to that in other regions, a distinct spatial distribution of glacier change has been observed. In general, glaciers closer to the sea showed larger changes compatible with a more maritime climate. In our study region, the analysis of length changes indicates that surge-type glaciers behaved similarly to normal glaciers but with a generally smaller retreat. It is thus not advisable to upscale the changes obtained only for the non-surge-type glaciers to the entire region, since this would considerably overestimate the change for regions with many surge-type glaciers such as found on Disko Island.

\section{ACKNOWLEDGEMENTS}

We thank J. Yde for providing data from Yde and Knudsen (in press) listing surge-type glaciers on Disko Island. We also thank the Geological Survey of Denmark and Greenland 
(GEUS) for granting permission to publish this research, an anonymous reviewer for careful and constructive comments that significantly improved the manuscript, and R. Mottram for valuable comments and for kindly reviewing the language quality of the manuscript. M.C.'s work is supported by DANCEA grant MST 112-00136, Danish Ministry of Climate and Energy. The satellite data used in this study were provided by the GLCF. F.P.'s work is supported by a grant from the European Space Agency project GlobGlacier (21088/07/I-EC).

\section{REFERENCES}

Andreassen, L.M., F. Paul, A. Kääb and J.E. Hausberg. 2008. Landsat-derived glacier inventory for Jotunheimen, Norway, and deduced glacier changes since the 1930s. Cryosphere, 2(2), 131-145.

Arctic Climate Impact Assessment (ACIA). 2004. Impacts of a warming Arctic: the Arctic Climate Impact Assessment. Cambridge, etc., Cambridge University Press.

Citterio, M. and 6 others. 2007. The fluctuations of Italian glaciers during the last century: a contribution to knowledge about Alpine glacier changes. Geogr. Ann., Ser. A, 89(3), 167-184.

Csatho, B., C.J. van der Veen and C. Tremper. 2005. Trimline mapping from multispectral Landsat ETM+ imagery. Géogr. Phys. Quat., 59(1), 49-62.

DeBeer, C.M. and M.J. Sharp. 2007. Recent changes in glacier area and volume within the southern Canadian Cordillera. Ann. Glaciol., 46, 215-221.

Dowdeswell, J.A. 1995. Glaciers in the High Arctic and recent environmental change. Philos. Trans. R. Soc. London, Ser. A, 352(1699), 321-334.

Hoelzle, M., W. Haeberli, M. Dischl and W. Peschke. 2003. Secular glacier mass balances derived from cumulative glacier length changes. Global Planet. Change, 36(4), 295-306.

Humlum, O. 1988. Rock glacier appearance level and rock glacier initiation line altitude: a methodological approach to the study of rock glaciers. Arct. Alp. Res., 20(2), 160-178.

Hutchinson, M.F. 1989. A new procedure for gridding elevation and stream line data with automatic removal of spurious pits. J. Hydrol., 106(3-4), 211-232.

Meier, M.F. and 7 others. 2007. Glaciers dominate eustatic sealevel rise in the 21st century. Science, 317(5841), 1064-1067.

Paul, F. and L.M. Andreassen. 2009. A new glacier inventory for the Svartisen region, Norway, from Landsat ETM+ satellite data: challenges and change assessment. J. Glaciol., 55(192), 607-618.

Paul, F. and A. Kääb. 2005. Perspectives on the production of a glacier inventory from multispectral satellite data in Arctic
Canada: Cumberland Peninsula, Baffin Island. Ann. Glaciol., 42, 59-66.

Paul, F. and F. Svoboda. In press. A new glacier inventory on southern Baffin Island, Canada, from ASTER data: II. Data analysis, glacier change and applications. Ann. Glaciol., 50(53) (see paper in this issue).

Paul, F., A. Kääb, M. Maisch, T. Kellenberger and W. Haeberli. 2002. The new remote-sensing-derived Swiss glacier inventory. I. Methods. Ann. Glaciol., 34, 355-361.

Paul, F., C. Huggel, A. Kääb, T. Kellenberger and M. Maisch. 2003. Comparison of TM-derived glacier areas with higher resolution data sets. EARSeL eProc., 2(1), 15-21.

Paul, F., A. Kääb, M. Maisch, T. Kellenberger and W. Haeberli. 2004. Rapid disintegration of Alpine glaciers observed with satellite data. Geophys. Res. Lett., 31(21), L21402. (10.1029/ 2004GL020816.)

Permanent Service on the Fluctuations of Glaciers (PSFG). 1977. Fluctuations of glaciers 1970-1975 (Vol. III), ed. Müller, F. Paris, International Commission on Snow and Ice of the International Association of Scientific Hydrology/UNESCO.

Racoviteanu, A.E., Y. Arnaud, M.W. Williams and J. Ordoñez. 2008. Decadal changes in glacier parameters in the Cordillera Blanca, Peru, derived from remote sensing. J. Glaciol., 54(186), 499-510.

Raper, S.C.B. and R.J. Braithwaite. 2006. Low sea level rise projections from mountain glaciers and ice caps under global warming. Nature, 439(7074), 311-313.

Raup, B. and 11 others. 2007. Remote sensing and GIS technology in the Global Land Ice Measurements from Space (GLIMS) Project. Comput. Geosci., 33(1), 104-125.

Solomon, S. and 7 others, eds. 2007. Climate change 2007: the physical science basis. Contribution of Working Group I to the Fourth Assessment Report of the Intergovernmental Panel on Climate Change. Cambridge, etc., Cambridge University Press.

Weidick, A., C.E. Böggild and N.T. Knudsen. 1992. Glacier inventory and atlas of West Greenland. Rapp. Grønl. Geol. Unders. 158.

Wolken, G.J. 2006. High-resolution multispectral techniques for mapping former Little Ice Age terrestrial ice cover in the Canadian High Arctic. Remote Sens. Environ., 101(1), 104-114.

Yde, J.C. and N.T. Knudsen. 2005. Glaciological features in the initial quiescent phase of Kuannersuit Glacier, Greenland. Geogr. Ann., Ser. A, 87(3), 473-485.

Yde, J.C. and N.T. Knudsen. 2007. 20th-century glacier fluctuations on Disko Island (Qeqertarsuaq), Greenland. Ann. Glaciol., 46, 209-214

Yde, J.C. and N.T. Knudsen. In press. Surge-type glaciers on Disko Island, Greenland. In Krugger, M.I. and H.P. Stern, eds. New permafrost and glacier research. Hauppauge, NY, Nova Science Publishers. 